\title{
Corporate Governance Structures and Probability of Financial Distress: Evidence From Indonesia Manufacturing Companies
}

\author{
Maria Goreti Kentris Indarti ${ }^{1}$, Jacobus Widiatmoko ${ }^{1} \&$ Imang Dapit Pamungkas ${ }^{2}$ \\ ${ }^{1}$ Faculty of Economics and Business, Universitas Stikubank Semarang, Indonesia \\ ${ }^{2}$ Faculty of Economics and Business, Universitas Dian Nuswantoro, Indonesia \\ Correspondence: Maria Goreti Kentris Indarti, Jl. Kendeng V Bendan Ngisor, Semarang, Indonesia.
}

Received: July 11, 2020

doi:10.5430/ijfr.v12n1p174
Accepted: September 7, 2020

Online Published: December 24, 2020

\begin{abstract}
This study aims to examine the effect of four variables, which include independent commissioners, audit committees, institutional ownership and managerial ownership as a proxy for the corporate governance mechanisms on financial distress. This was carried out on the manufacturing companies listed on the Indonesia Stock Exchange (IDX) in 2016-2018. The samples were selected using the purposive sampling method and 224 data were obtained. The hypothesis in this study was tested using logistic regression. The results showed that independent commissioners have a negative influence on financial distress, while the audit committee, institutional ownership and managerial ownership have no effect. This implies that an independent commissioner functions as an effective supervisory mechanism to prevent a company from experiencing financial distress. Furthermore, two control variables used in this study, namely leverage and profitability, were able to produce results as predicted. It was discovered that a higher leverage level leads to a greater possibility of experiencing financial distress and conversely, the higher the profitability of a company, the lower the probability of experiencing financial distress.
\end{abstract}

Keywords: corporate governance, financial distress, logistic regression

\section{Introduction}

Financial Distress is a condition in which a company experiences financial difficulties before finally becoming bankrupt (Mafiroh \& Triyono, 2018). Some signs of financial difficulties include Increases in capital costs, more stringent requirements from creditors and suppliers for corporate financing, decreased cash flow, increased financial leverage and regular changes of key employees. These difficulties are caused by inefficient and ineffective operational system, deficiencies in market conditions such as recession and decline in market share and mismanagement of the company (Kordestani et al., 2011). Meanwhile, when the prediction of a company's financial distress is reliable, it provides a lot of benefits, such as the company managers taking corrective steps to avoid difficulties before bankruptcy occurs and investors understanding the profitability situation therefore, adjusting their investment strategies to reduce investment-related losses. However, the rapid development of capital markets and global economic integration has increased the number of companies that have experienced financial difficulties over the years (Geng et al., 2015).

In addition, having good corporate governance enhances the economic development of a country. This is because its implementation strengthens the performance and protects companies against the risk of financial distress (Murhadi et al., 2018). Furthermore, the structure fosters accountability and transparency with the aim of minimizing agency problems due to the separation between managers and shareholders, which is realized in the form of effective supervision and management (Adegboye et al., 2019). When a company has a weak corporate governance mechanism structure, more agency problems tend to occur (Nasir \& Ali, 2018), leading to the possibility of a financial distress. Therefore, good corporate governance practices are needed to strengthen the performances and prevent financial distress.

According to agency theory, one important element in corporate governance is the board of commissioners (Nasir \& Ali, 2018). They are considered a major component because of their role in monitoring the company's performance. An independent commissioner is a member of the board of commissioners outside the company, whose existence is expected to be able to place justice as the main principle in paying attention to the interests of those who may often be 
ignored. Therefore, a higher proportion of independent commissioners leads to lower possibility of experiencing financial distress. Previous studies Fathonah, (2017); Miglani et al., (2015) proved that their existence in a company improves oversight function which ensures efficient and effective management. Conversely, Helena \& Saifi, (2017); Mafiroh \& Triyono, (2018); Nasir \& Ali, (2018); Murhadi et al., (2018) did not find any negative influence of the independent commissioners towards financial distress. Another element is the audit committee, responsible for assisting and strengthening the function of the board of commissioners in carrying out the oversight functions of the financial reporting process, risk management, conducting audits and implementation of corporate governance. Therefore, their existence strengthens the monitoring function, which in turn reduces the possibility of the occurrence of financial distress (Miglani et al., 2015). The study carried out by Miglani et al., (2015) on companies in Egypt proved that the audit committee was able to prevent financial pressure. However, several studies which were carried out in Indonesia did not find evidence of their negative influence on financial distress (Fathonah, 2017; Helena \& Saifi, 2017; Mafiroh \& Triyono, 2018).

Institutional ownership is associated with families and other strong players, who have access to a wider network, which may be utilized on long-term performance. Therefore, when other corporate governance mechanisms are ineffective, institutional investors take an active role to control the managers (Manzaneque et al., 2016). However, Shahwan, (2015) in Egypt and Mafiroh \& Triyono, (2018) in Indonesia did not find any negative effect of institutional ownership on financial distress. This was because shareholder institutions have an interest in manipulating financial statements for various purposes. In addition, the quality of good corporate governance practices in Egypt was low and therefore, the results were not significant (Shahwan, 2015).

Furthermore, according to agency theory, Managerial ownership plays an important and positive role in improving a company's financial performance. This is because when the managers are also shareholders, they will act in the best interests of the company. They also tend to be cautious when handling affairs, which leads to better efficiency, Jensen \& Meckling, (1976) and prevents the occurrence of financial distress. In addition, the studies carried out by Luqman et al., (2018); Manzaneque et al., (2016); Miglani et al., (2015), further proved that the higher the number of shares owned by the managers, the better the efficiency. Deviacita, (2012), examined the effect of managerial ownership on financial distress in Indonesia and the results showed that it has a negative effect on financial distress. This is because it provides additional incentives for managers to oversee the policies that have been set therefore, reducing the opportunistic behavior and aligning the interest of other shareholders. Based on the description above, there is still a controversy about the impact of corporate governance on financial distress, especially in developing countries (Shahwan, 2015). Therefore, this study expands the existing literature by examining the effect of the quality of corporate governance practices on the possibility of financial distress in a company.

\section{Literature Review \& Hypothesis Development}

\subsection{Agency Theory, Financial Distress \& Corporate Governance}

The agency theory explains the contractual relationship between shareholders as principals and managers as agents (Jensen \& Meckling, 1976). The problem that arises from this agency relationship is a conflict of interest, because the agent does not always act in the interests of the principal. However, this conflict is minimized by monitoring mechanisms through good corporate governance, which leads to aligned interests and therefore, a decrease in agency cost. In addition, good corporate governance is also employed to minimize moral hazard and encourage the managers to handle the company efficiently (Chabachib et al., 2020).

Financial Distress is a situation in which a company's profitability decreases, which leads to an increase in the possibility of its inability to pay the principal and interest of a debt. Kordestani et al., (2011) divides the bankruptcy process into 4 (four) stages, namely latency, shortage of cash, financial distress and bankruptcy. At the latency stage, it is predicted that the company's return on assets will decrease significantly. The company does not have sufficient cash resources to meet current obligations at the shortage of cash stage although, it may still have strong profitability background. The financial distress stage is considered as a condition where financial emergencies occur. When a company is unable to recover from the symptoms of financial distress, bankruptcy is certified. A bankrupt company is characterized by negative equity, because it has lost all of its net worth after years of financial losses. Consequently, they no longer have enough resources to cover liabilities, but continue to carry out business (Urionabarrenetxea et al., 2016).

The Corporate Governance is a set of rules, procedures and administration of a company's contract with shareholders, creditors, employees, suppliers, customers and the government. Legally, it is placed in the hands of the board of directors who have a fiduciary obligation to serve corporate interests rather than theirs or that of the company's managers (Lakshan \& Wijekoon, 2012). 


\subsection{Independent Commissioners on Financial Distress}

The existence of an independent commissioner assists in monitoring and controlling the managers (Jensen \& Meckling, 1976). They are the number of commissioners in companies that come from independent parties. When the board of commissioners comprises more of independent commissioners, it is expected that the oversight and coordination functions will run better (Widiatmoko et al., 2020). This is because they are the core of corporate governance which serve to guarantee the implementation of corporate strategy, oversee company managers and encourage accountability. Therefore, an increasing number of them in the board of commissioners lead to a better company performance and the possibility of financial distress is reduced (Nasir \& Ali, 2018). In addition, they tend to initiate a corporate restructuring strategy when the company is performing poorly, which increases the company's operating performance (Utomo et al., 2018).

The negative influence of independent commissioners on financial distress was stated by Miglani et al., (2015) who carried out a study on the companies listed on the Australian stock exchange. In addition, Manzaneque et al., (2016) examined their influence on the possibility of financial distress on companies listed on the Spanish Stock Exchange in 2007-2012. Similar results were also obtained by (Luqman et al., 2018). Fathonah, (2017), which provided an evidence of the negative influence of independent commissioners on financial distress in the property sector companies listed on the Indonesia Stock Exchange in 2013. It was discovered that a higher number of independent commissioners, leads to a lesser tendency of experiencing financial distress. Therefore, the following hypothesis was formulated.

\section{H1: Independent Commissioners have a negative effect on Financial Distress}

\subsection{The Audit Committee on Financial Distress}

Supervision is one important component in the corporate governance mechanism. In accordance with agency theory, good quality supervision reduces opportunistic behavior by managers as agents. One effort to create a good oversight mechanism is the existence of an audit committee in a company (Widiatmoko, 2020). The audit committee is responsible to the board of commissioners with the purpose of assisting them in carrying out the oversight function of running of the company. Their existence is intended to improve corporate governance in accordance with agency theory, especially on how to oversee company's management. They act as a liaison between the managers, board of commissioners and other external parties (Pamungkas et al., 2018). Together with the company's auditors, they ensure that the company's audited financial statements accurately reflect the financial condition (Platt \& Platt, 2012). Therefore, the existence of an audit committee in a company prevents the possibility of financial distress. This is in line with the discoveries of Irwandi et al., (2019) that the existence of an audit committee correlates with the company's financial status. The study carried out by Luqman et al., (2018) on the companies listed on the Karachi Stock Exchange also proved that their existence of an audit reduces the possibility of financial distress. Based on the logic and empirical support above, the following hypothesis was formulated.

\section{H2: The Audit Committee has a negative effect on Financial Distress}

\subsection{Institutional Ownership on Financial Distress}

Institutional ownership is the proportion of ordinary shares owned by institutional parties (Helena \& Saifi, 2018). Institutional shareholders are motivated to manage the company efficiently, because they have a large investment and authority to make decisions which improves the company's financial performance (Jensen \& Meckling, 1976). Therefore, when the company's financial performance is lower than expected, they are able to dismiss directors based on their authority. Therefore, this condition pressures managers to work in the best interests of the company rather than theirs (Luqman et al., 2018).

Deviacita, (2012), examined the effect of institutional ownership on financial distress in manufacturing companies listed on the Indonesia Stock Exchange in 2006-2010 and proved that stock ownership by institutions has a negative effect on the possibility of financial distress. This same result was obtained by Core \& Guay, (1999); Helena \& Saifi, (2017). The ownership of a larger institution significantly improves supervision of financial conditions, which becomes a reference and motivation for company managers to improve their performance and preventing financial distress. Therefore, the following hypothesis was formulated.

\section{H3: Institutional Ownership has a negative effect on Financial Distress.}

\subsection{Managerial Ownership on Financial Distress}

Managerial Ownership is the number of shares owned by managers of the total number of shares outstanding (Widhiastuti, Nurkhin, \& Susilowati, 2019). When the managers are also shareholders, they carry out their duties in the 
best interests of the company. In addition, they tend to be a lot more careful in carrying out operations, which leads to efficient management (Mitchell et al., 2011). Therefore, when the shares of managers continuously increases, their decisions and actions aims towards the reduction of the possibility of financial distress (Luqman et al., 2018). Deviacita, (2012), also examined the effect of managerial ownership on financial distress of the manufacturing companies listed on the Indonesia Stock Exchange in 2006-2010. The test results showed that the greater the number of shares owned by managers, the lesser the tendency of experiencing financial distress. Furthermore, consistent results were also obtained when two set of companies were tested with the same number of samples from each group, i.e. 34 companies each in the group that did and did not experience financial distress.

Manzaneque et al., (2016), stated that managerial ownership is a factor that reduces conflicts of interest which arise between majority and minority shareholders. Primarily in the context of concentrated ownership such as the Spanish capital market, managerial ownership is important to reduce the possibility of company failure. Luqman et al., (2018) also discovered a negative effect of this variable on financial distress therefore, when the managerial ownership is high, it leads to a low possibility of financial distress. This is because increased share ownership by managers enables them to directly feel the benefits of the decisions taken. Furthermore, they partake in losses that arise when wrong decisions are taken. Therefore, the following hypothesis was formulated.

\section{H4: Managerial Ownership has a negative effect on Financial Distress}

\section{Methods}

This study was carried out on all manufacturing companies listed on the Stock Exchange in 2016-2018. The process of sample selection, using purposive sampling method is presented in Table 1.

Table 1. Population and study samples

\begin{tabular}{lccc}
\hline & 2016 & 2017 & 2018 \\
\hline $\begin{array}{l}\text { Population: } \\
\text { Manufacturing companies listed on the Stock Exchange in 2016-2018 }\end{array}$ & 149 & 161 & 169 \\
\hline Sample Criteria: & $(19)$ & $(19)$ & $(21)$ \\
Manufacturing companies that do not publish Annual Report 2016-2018 & $(1)$ & $(2)$ & $(19)$ \\
Manufacturing companies that do not publish audited financial statements & $(60)$ & $(63)$ & $(51)$ \\
$\begin{array}{l}\text { Manufacturing companies that do not provide complete data regarding research } \\
\text { variables }\end{array}$ & 69 & 77 & 78 \\
Final Samples & & 224 & \\
\hline Total of data
\end{tabular}

As shown in Table 1, it is seen that the number of samples obtained in 2016-2018 were 69, 77 and 78, respectively therefore, the total data analyzed were 224. The dependent variable used in this study was financial distress. Independent commissioner, audit committee, institutional ownership, and managerial ownership were used as independent variables, while leverage and profitability were used as control variables. The financial distress was measured by earnings per share (Chabachib et al., 2019), because it describes how the company is able to generate profits per share obtained from its operations. The negative earnings per share indicate that the company is experiencing operating losses. Financial distress was measured using a dummy variable, which is number 1 or 0 when the company either has negative or positive earnings per share.

Independent commissioners were measured using a proportion of the number of independent board of commissioners to the total board of commissioners (Fathonah, 2017). The audit committee was measured using a ratio between independent audit committee and all members of the audit committee (Irwandi et al., 2019). Institutional ownership was measured by the ratio between the number of shares owned by institutional investors and the total shares of the company (Chabachib et al., 2019). The last variable which is managerial ownership was measured by the ratio between the number of shares owned by managers and the number of shares outstanding (Deviacita, 2012). Leverage and profitability as control variables were each measured using the ratio between total debt to total assets and the ratio between net income to total assets (Mafiroh \& Triyono, 2018).

The data analysis method used in this study was logistic regression, with the mathematical equation as follows:

$$
\text { Ln } p /(1-p)=\alpha+\beta_{1} \text { IndCom }+\beta_{2} \text { AuditCom }+\beta_{3} \text { InstOwn }+\beta_{4} \text { ManOwn }+\beta_{5} \operatorname{Lev}+\beta_{6} \text { Prof }+e
$$




$\begin{array}{ll}\text { Ln p/(1-p) } & : \text { The probability of a company experiencing financial distress } \\ \alpha & : \text { Constant } \\ \beta & : \text { Regression coefficient } \\ \text { IndCom } & : \text { Independent commissioner } \\ \text { AuditCom } & : \text { Audit committee } \\ \text { InstOwn } & : \text { Institutional ownership } \\ \text { ManOwn } & : \text { Managerial ownership } \\ \text { Lev } & : \text { Leverage } \\ \text { Prof } & : \text { Profitability } \\ \text { e } & : \text { Error term }\end{array}$

\section{Results}

\subsection{Hosmer and Lemeshow}

From the Hosmer and Lemeshow Goodness of Fit Test results, a value of 0.009 , less than 0.05 was obtained in the first stage, which indicated that the Model was not fit. However, the test was carried out again after eliminating 16 outlier data and the results are presented in Table 2.

Table 2. Hosmer and Lemeshow Test Results

\begin{tabular}{llll}
\hline Step & Chi-squere & Df & Sig \\
\hline 1 & 7.183 & 8 & 0.517 \\
\hline
\end{tabular}

As shown in Table 2, the value of Hosmer and Lemeshow Goodness of Fit was 7.183 with a significance value of 0.517 , greater than 0.05 . Therefore, it was concluded that the model is able to predict the value of its observations or said to be fit and acceptable because it matches the observational data.

\subsection{Chi Square Test}

Chi-square testing for the whole model of the data was carried out by comparing the value of both the $-2 \log$ likelihood at the beginning (block number 0 results) and end (block number 1 results). When there is a decrease, it is said to be a good regression model.

Table 3. Likelihood Overall Test Results

\begin{tabular}{cccc}
\hline Block 0 & & & \\
\hline & Iteration & & -2Log Likelihood \\
\hline Step 0 & 1 & & 190.771 \\
& 2 & & 188.516 \\
& 3 & & 188.503 \\
& 4 & & 188.503 \\
\hline Block 1 & & & \\
\hline Iteration & & -2Log Likelihood & \\
\hline Step 1 & 1 & 173.603 & \\
& 2 & 164.907 & \\
& 3 & 163.996 & \\
& 4 & 163.982 & \\
& 5 & 163.982 & \\
& 6 & 163.982 & \\
\hline
\end{tabular}


As shown in Table 3, Block Number 0 and 1 obtained $-2 \log$ likelihood values of 188.503 and 163.982 respectively. Based on these figures, it is seen that the value of $-2 \log$ likelihood decreased. This condition indicated that the regression model used in this study was good or hypothesized to be fit with the data. The decline in the value of $-2 \log$ likelihood is presented as the chi square value in the omnibus test of model coefficient in Table 4.

Table 4. Omnibus Test of Model Coefficient

\begin{tabular}{cccc}
\hline & $\begin{array}{c}\text { Chi- } \\
\text { square }\end{array}$ & Df & Sig. \\
\hline Step 1 Step & 24.521 & 6 & 0.000 \\
Block & 24.521 & 6 & 0.000 \\
Model & 24.521 & 6 & 0.000 \\
& & & \\
\hline
\end{tabular}

From Table 4, it is seen that the chi square value (decreasing log-likelihood value) was 24.521 , with a significance value of 0.000 , which indicated that the variables of independent commissioners, audit committee, institutional ownership and managerial ownership explains the variations in financial distress.

\subsection{Cox and Snell's $R$ Square and Nagelkereke's $R$ Square}

Table 5. Cox and Snell's R Square and Nagalkereke's R Square

\begin{tabular}{cccc}
\hline Step & $\begin{array}{c}-2 \text { Log } \\
\text { Likelihood }\end{array}$ & $\begin{array}{c}\text { Cox \& } \\
\text { Snell R } \\
\text { Square }\end{array}$ & $\begin{array}{l}\text { Nagalkerke } \\
\text { R Square }\end{array}$ \\
\hline 1 & 163.982 & 0.111 & 0.187 \\
\hline
\end{tabular}

As shown in Table 5, the value of Nagellkerke's R Square obtained was 0.187 or $18.7 \%$, which indicated that the variables of independent commissioners, audit committee, institutional ownership, managerial ownership, leverage and profitability explained $18.7 \%$ of the financial distress, while the remaining $81.3 \%$ was explained by other variables outside the study model.

\subsection{The $2 \times 2$ Classification Table}

The $2 \times 2$ classification table shows the power of a regression model in predicting the likelihood of a company experiencing financial distress. The classification results are presented in Table 6.

Table 6. The $2 \times 2$ Classification Table

\begin{tabular}{crrrr}
\hline \multirow{2}{*}{ Observed } & \multicolumn{3}{c}{ Predicted } \\
\cline { 2 - 4 } & & 0 & 1 & Percentage \\
\cline { 2 - 4 } & & 172 & 1 & 99,4 \\
& & 32 & 3 & 8,6 \\
Step 1 FD & 1 & & & 84,1 \\
& & & & \\
Overall & & & \\
Percentage & & &
\end{tabular}

From Table 6, it is seen that 173 companies have a healthy financial status (non-financial distress) and 172 companies or $99.4 \%(172 / 173)$ were accurately predicted by the regression model. In total, $172+3=176$ companies from the 208 company samples or $84.1 \%$ were accurately predicted by the regression model. This high percentage supports the conclusion that there is no significant difference between the predicted and observational data, therefore, showing a good regression model. 


\subsection{Hypothesis Testing Results}

The results of the hypothesis testing in this study are presented in Table 7. It is seen that the Independent Commissioners (IndCom) had a beta coefficient of -5.147 with a significance value of 0.038 , lesser than 0.05 , which indicated that it had a significant negative effect on financial distress. Therefore, $\mathrm{H} 1 \mathrm{which}$ states that the independent commissioner has a negative effect on financial distress was accepted. The Audit Committee (AuditCom) showed a beta coefficient of -2.921 with a significance value of 0.163 , greater than 0.05 , which indicated that it had no effect on financial distress. Therefore, $\mathrm{H} 2$ which states the audit committee has a negative effect on financial distress was rejected. The institutional ownership variable (InstOwn) had a beta coefficient of 1.443 with a significance level of 0.106 , greater than 0.05 which indicated that it had no effect on financial distress. Therefore, H3 which states that institutional ownership has a negative effect on financial distress was rejected. The last variable, managerial ownership (ManOwn) had a beta coefficient of 1.035 with a significance value of 0.382 , greater than 0.05 which indicated that it had no effect on financial distress. Therefore, $\mathrm{H} 4$ which states that managerial ownership has a negative effect on financial distress was rejected.

Table 7. Hypothesis Testing Results

\begin{tabular}{|c|c|c|c|c|c|c|c|c|}
\hline & \multicolumn{8}{|c|}{ Variables in the Equation } \\
\hline & & B & S.E. & Wald & Df & & Sig. & $\operatorname{Exp}(B)$ \\
\hline \multirow[t]{7}{*}{ Step $1^{\mathrm{a}}$} & IndCom & -5.147 & 2.480 & 4.308 & & 1 & 0.038 & 0.006 \\
\hline & AuditCom & -2.921 & 2.094 & 1.946 & & 1 & 0.163 & 0.054 \\
\hline & InstOwn & 1.443 & 0.892 & 2.617 & & 1 & 0.106 & 4.234 \\
\hline & ManOwn & 1.035 & 1.185 & 0.763 & & 1 & 0.382 & 2.816 \\
\hline & Lev & 3.020 & 0.912 & 10.962 & & 1 & 0.001 & 20.239 \\
\hline & Prof & -2.271 & 1.359 & 2.792 & & 1 & 0.095 & 0.103 \\
\hline & Constant & -0.249 & 1.584 & 0.025 & & 1 & 0.875 & 0.780 \\
\hline
\end{tabular}

As shown in Table 7, Leverage (Lev) as a control variable had a beta coefficient of 3.020 with a significance value of 0.001 , lesser than 0.05 and as predicted it had a positive effect on financial distress. The profitability variable (Prof) had a beta coefficient of -2.271 with a significance level of 0.095 which indicated that it had a positive effect on financial distress at an alpha level of $10 \%$. Therefore, it was concluded that leverage and profitability are able to function as control variables.

\section{Discussion}

From the logistic regression test results, it was proven that the independent commissioners have a negative effect on financial distress. This implies that their existence in the structure of the company's board of commissioners minimizes the occurrence of financial distress and in line with agency theory, also ensures adequate control over the managers. Furthermore, the opportunistic nature and selfish behavior of managers is reduced therefore, decision making is consistent with the interests of shareholders (Jensen \& Meckling, 1976; Manzaneque et al., 2016). The results of this study were also in line with the discoveries of Fathonah, (2017); Helena \& Saifi, (2017), which proved that an independent commissioner is able to function as a good corporate governance mechanism in preventing the occurrence of financial distress. Furthermore, the results obtained support the discoveries of (Luqman et al., 2018) which proved that the existence of an external commissioner reduced the potential of financial distress in companies on the Karachi Stock Exchange.

However, this study found no evidence of the negative influence of the audit committee on financial distress. This condition was contrary to the agency theory which states that an audit committee in a company works as an internal corporate governance mechanism to reduce agency costs and plays an important role in helping the board of commissioners fulfill their corporate governance responsibilities (Miglani et al., 2015). Companies with this committee are expected to perform better compared to those without them in avoiding financial distress. The findings in this study also contradict those of Luqman et al., (2018); Miglani et al., (2015) which proved that the existence of an audit committee prevents the occurrence of financial distress in a company. Meanwhile, the results obtained in this 
study were in line with that of Fathonah, (2017); Helena \& Saifi, (2017); Mafiroh \& Triyono, (2018) which showed that the audit committee has no effect on financial distress. Their existence in public companies until now is only to meet the provisions of the regulator. This was indicated by the appointment of members in public companies, which was mostly based not on adequate competence and capability, but on proximity to the company's board of commissioners (Helena \& Saifi, 2017).

Furthermore, the results showed that the number of shares owned by institutional investors did not affect the financial distress condition of a company. This was not in line with the results of the study carried out by Chabachib et al., (2019; Helena \& Saifi, (2017), which proved that they play a role in reducing the possibility of a company's financial distress, including the agency theory. Jensen \& Meckling, (1976) stated that institutional investors have an incentive to monitor the actions and decision making of company managers. This is carried out as a way to maximize the value of their share ownership and equally minimize the potential for losses due to financial difficulties or failures. Conversely, the results of this study were consistent with previous findings, namely Chabachib et al., (2019); Manzaneque et al., (2016) which showed that the existence of institutional investors is not able to reduce the possibility of companies experiencing financial distress. The reason for this was because they have a passive monitoring role in the management activities of a company. Managerial ownership variables in this study were also not proven to be able to reduce the possibility of companies experiencing financial distress although, problems between managers and shareholders is handled by increasing managerial ownership and control. This is because increasing share ownership in a company will align both the interests of the managers and shareholders. However, controlling agency costs by increasing managerial stock ownership is not free, because as the wealth of the managers becomes more diverse, the amount of compensation increases. Therefore, the number of shares owned by managers does not affect the company's financial distress. Meanwhile, the results of this study were in line with the findings of (Fathonah, 2017). Similar results were also obtained by Udin et al., (2017), who discovered that managerial ownership had no effect on financial distress in Pakistan. The main reason behind the results was the low quality of corporate governance practices in Pakistan.

The logistic regression test results showed that leverage as a control variable has a positive effect on financial distress, which was as predicted. Therefore, a higher leverage level, leads to a greater possibility for financial distress to occur. This is because when companies accrue too much debt, it leads to risk of difficulties in payment of the principal debt and interest or experiencing financial distress. The profitability variable in this study also functions as a control variable and as predicted, it affects the financial distress of a company. Therefore, the higher the ability of a company to generate profits, the lower the possibility of experiencing financial distress.

\section{Conclusion}

This study examined and analyzed the influence of independent commissioners, audit committee, institutional ownership and managerial ownership as a proxy for corporate governance mechanisms on financial distress in manufacturing companies listed on the Indonesia Stock Exchange in 2016-2018. It was discovered that managerial ownership does not affect financial distress, because the amount of shares owned by managers is not able to influence their activities in running the company. Furthermore, as predicted, leverage as a control variable showed a positive influence, while profitability had a negative effect on financial distress. Apart from the contributions that may be made, this study has several limitations therefore, development and improvement is required in subsequent studies.

A limitation is the low feasibility test results for the whole model, which was equal to $18.7 \%$. This shows that the variables in this study were only able to explain $18.4 \%$ of the variations in financial distress, while $81.3 \%$ were explained by other variables not included in this study. In addition, only the independent commissioners of the four variables used as a proxy for corporate governance mechanisms, had an influence on financial distress. Based on the findings and limitations in this study, the proxy of other corporate governance mechanisms should be considered in subsequent studies. Cumulative grade percentile index (CGPI) is used to measure corporate governance mechanisms whose calculations were based on various aspects of commitment, transparency, accountability, responsibility, independence, fairness, compensation, leadership, ability to work together, the realization of vision, mission, and corporate governance, moral ethics and strategy. In addition, external corporate governance mechanisms, such as audit quality and opinion as determinants of a company's financial distress should be considered.

\section{References}

Adegboye, A., Ojeka, S., Adegboye, K., Ebuzor, E., \& Samson, D. (2019). Firm performance and condensed corporate governance mechanism: Evidence of Nigerian financial institutions. Business: Theory and Practice, 20, 403-416. https://doi.org/10.3846/btp.2019.38

Chabachib, M., Fitriana, T. U., Hersugondo, H., Pamungkas, I. D., \& Udin, U. (2019). Firm value improvement 
strategy, corporate social responsibility, and institutional ownership. International Journal of Financial Research, 10(4), 152-163. https://doi.org/10.5430/ijfr.v10n4p152

Chabachib, M., Hersugondo, H., Hidayat, R., \& Pamungkas, I. D. (2020). Corporate Governance, Firm Performance and Capital Structure: Evidence From Indonesia. Research in World Economy, 11(1), 48-55. https://doi.org/10.5430/rwe.v11n1p48

Chabachib, M., Kusmaningrum, R. H., Hersugondo, H., \& Pamungkas, I. D. (2019). Financial distress prediction in Indonesia. WSEAS Transactions on Business and Economics, 16(2015), 251-260.

Ciftci, I., Tatoglu, E., Wood, G., Demirbag, M., \& Zaim, S. (2019). Corporate governance and firm performance in emerging markets: Evidence from Turkey. International Business Review, 28(1), 90-103. https://doi.org/10.1016/j.ibusrev.2018.08.004

Core, J., \& Guay, W. (1999). The use of equity grants to manage optimal equity incentive levels. Journal of Accounting and Economics, 28(2), 151-184. https://doi.org/10.1016/S0165-4101(99)00019-1

Deviacita, A. W. (2012). Analisis Pengaruh Mekanisme Corporate Governance Terhadap Financial Distress. Diponegoro Journal of Accounting, 1(1), 1-14. Retrieved from http://ejournal-s1.undip.ac.id/index.php/accounting

Fathonah, A. N. (2017). Pengaruh Penerapan Good Corporate Governance Terhadap Financial Distress. Jurnal Ilmiah Akuntansi, 1(2), 133-150. https://doi.org/10.23887/jia.v1i2.9989

Geng, R., Bose, I., \& Chen, X. (2015). Prediction of financial distress: An empirical study of listed Chinese companies using data mining. European Journal of Operational Research, 241. https://doi.org/10.1016/j.ejor.2014.08.016

Helena, S., \& Saifi, M. (2017). Pengaruh Corporate Governance Terhadap Financial Distress. Universitas Brawijaya Malang, 47(1), 103-112.

Irwandi, S. A., Ghozali, I., Faisal, \& Pamungkas, I. D. (2019). Detection fraudulent financial statement: Beneish m-score model. WSEAS Transactions on Business and Economics, 16, 271-281.

Jensen, M. C., \& Meckling, W. H. (1976). Theory of the Firm: Managerial. Journal of Financial Economics, 3, 305-360. https://doi.org/10.1016/0304-405X(76)90026-X

Kordestani, G., Biglari, V., \& Bakhtiari, M. (2011). Ability of combinations of cash flow components to predict financial distress. Business: Theory and Practice, 12(3), 277-285. https://doi.org/10.3846/btp.2011.28

Lakshan, A. M. I., \& Wijekoon, W. M. H. N. (2012). Corporate Governance and Corporate Failure. Procedia Economics and Finance, 2(Af), 191-198. https://doi.org/10.1016/s2212-5671(12)00079-2

Luqman, R., Ul hassan, M., Tabasum, S., Khakwani, M. S., \& Irshad, S. (2018). Probability of financial distress and proposed adoption of corporate governance structures: Evidence from Pakistan. Cogent Business and Management, 5(1), 1-14. https://doi.org/10.1080/23311975.2018.1492869

Mafiroh, A., \& Triyono, T. (2018). Pengaruh Kinerja Keuangan dan Mekanisme Corporate Governance terhadap Financial Distress (Studi Empiris pada Perusahaan Manufaktur yang Terdaftar di Bursa Efek Indonesia Periode 2011-2014). Riset Akuntansi dan Keuangan Indonesia, 1(1), 46-53. https://doi.org/10.23917/reaksi.v1i1.1956

Manzaneque, M., Priego, A. M., \& Merino, E. (2016). Corporate governance effect on financial distress likelihood: Evidence from Spain. Revista de Contabilidad-Spanish Accounting Review, 19(1), 111-121. https://doi.org/10.1016/j.rcsar.2015.04.001

Miglani, S., Ahmed, K., \& Henry, D. (2015). Voluntary corporate governance structure and financial distress: Evidence from Australia. Journal of Contemporary Accounting and Economics, 11(1), 18-30. https://doi.org/10.1016/j.jcae.2014.12.005

Mitchell, R. J., Lenne, J., \& Ramsay, I. (2011). Employee Share Ownership Schemes in Australia: A Survey of Key Issues and Themes. SSRN Electronic Journal, (129). https://doi.org/10.2139/ssrn.809944

Nasir, N. M., \& Ali, M. M. (2018). Corporate governance and financial distress: Malaysian perspective. Asian Journal of Accounting Perspectives, 11(1), 108-128.

Pamungkas, I. D., Ghozali, I., \& Achmad, T. (2018). A pilot study of corporate governance and accounting fraud: The fraud diamond model. Journal of Business and Retail Management Research, 12(2). 
Platt, H., \& Platt, M. (2012). Corporate board attributes and bankruptcy. Journal of Business Research, 65(8), 1139-1143. https://doi.org/10.1016/j.jbusres.2011.08.003

Ria Murhadi, W., Tanugara, F., \& Silvia Sutejo, B. (2018). The Influence of Good Corporate Governance (GCG) on Financial Distress. Proceedings of the 15th International Symposium on Management (INSYMA 2018), 186, 76-79. https://doi.org/10.2991/insyma-18.2018.19

Sari, M. P., Hajawiyah, A., Raharja, S., \& Pamungkas, I. D. (2020). The report of university sustainability in Indonesia. International Journal of Innovation, Creativity and Change, 11(8), 110-124.

Shahwan, T. M. (2015). The effects of corporate governance on financial performance and financial distress: evidence from Egypt. Corporate Governance (Bingley), 15(5), 641-662. https://doi.org/10.1108/CG-11-2014-0140

Udin, S., Khan, M. A., \& Javid, A. Y. (2017). Corporate Governance: The International Journal of Business in Society The Effects of Ownership Structure on likelihood of Financial Distress: An Empirical Evidence Article information: About Emerald www.emeraldinsight.com. Corporate Governance: International Journal of Business Society, 14(4), 589-612. https://doi.org/https://doi.org/10.1108/CG-03-2016-0067

Urionabarrenetxea, S., San-Jose, L., \& Retolaza, J. L. (2016). Negative equity companies in Europe: Theory and evidence. Business: Theory and Practice, 17(4), 307-316. https://doi.org/10.3846/BTP.17.11125

Utomo, S. D., Pamungkas, I. D., \& Machmuddah, Z. (2018). The moderating effects of managerial ownership on accounting conservatism and quality of earnings. Academy of Accounting and Financial Studies Journal, 22(6), $1-11$.

Widhiastuti, R., Nurkhin, A., \& Susilowati, N. (2019). The Role of Financial Performance in Mediating The Effect of Good Corporate Governance on Financial Distress. Jurnal Economia, 15(1), 34-47. https://doi.org/10.21831/economia.v15i1.22927

Widiatmoko, J. (2020). Corporate Governance Mechanism and Corporate Social Responsibility on Firm Value. Relevance: Journal of Management and Business, 3(1), 13. https://doi.org/10.22515/relevance.v3i1.2345

Widiatmoko, J., Indarti, M. G. K., \& Pamungkas, I. D. (2020). Corporate governance on intellectual capital disclosure and market capitalization. Cogent Business and Management, 7(1), 0-14. https://doi.org/10.1080/23311975.2020.1750332

\section{Copyrights}

Copyright for this article is retained by the author(s), with first publication rights granted to the journal.

This is an open-access article distributed under the terms and conditions of the Creative Commons Attribution license (http://creativecommons.org/licenses/by/4.0/). 